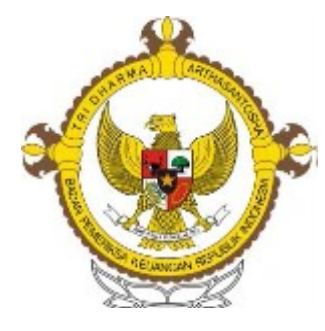

JURNAL

TATA KELOLA DAN AKUNTABILITAS KEUANGAN NEGARA

Volume 6, Number 2, Jul-Dec 2020, 179-194

e-ISSN 2549-452X

p-ISSN 2460-3937

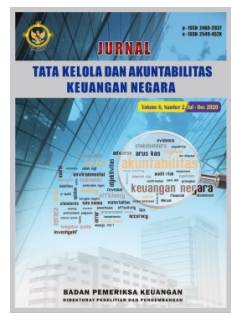

\title{
ARE LOCAL GOVERNMENTS OVERCONFIDENT WITH THE EFFECT OF BUDGET FORECAST ERRORS ON BUDGET DEVIATION?
}

\author{
Amor Marundha \\ Department of Accounting \\ Bhayangkara Jakarta Raya University, Indonesia \\ Amor.marundha@dsn.ubharajaya.ac.id
}

\begin{abstract}
This study aims to examine the effect of budget forecast errors on budget deviations moderated by local governments' overconfidence. The research sample used regency/city governments in Indonesia during the 2017-2019 period. The analysis tool uses Eviews version 10 and SPSS version 22. The results showed that budget forecast errors had a positive and significant effect on budget deviation, but the local government's overconfidence cannot cause an effect of budget forecast errors on the budget deviation. Additional test results of this study also showed that regency/city governments who were overconfident tend to fail in controlling their budget which could cause a surplus or deficit compared to local governments that were not overconfident. The same conditions apply to budget forecast errors. This means that regency/city governments that are overconfident tend to estimate budgets that are too high for revenue and/or budget estimates that are too low for expenditure compared to local governments that are not overconfident. Consistent with the main test results, this study shows that budget forecast errors have a significant effect on budget deviation and tend to occur in the Central Indonesian region category. Furthermore, overconfident regency/city governments cannot moderate the effect of budget forecast errors on budget deviations. Finally, these findings indicate that there is no difference between the budget forecast errors and the budget deviation in the three categories of western, central, and eastern Indonesia.
\end{abstract}

\section{KEYWORDS:}

Budget forecast errors; local government overconfidence; budget deviation

DOI: $10.28986 /$ jtaken.v6i2.480 


\section{INTRODUCTION}

A budget is an organization's financial planning for the future that contains the goals and actions needed by the organization in achieving these goals and generally covers a period of one year. This budget is translated into more concrete financial programs and plans and used by the organization to achieve organizational goals. Ratmono and Sholihin (2017) explain that a budget as a public policy statement, fiscal target, and as a means of control has an important influence in financial accounting and reporting. This condition occurs because the budget is a fiscal target that describes the balance between expenditure, revenue, and desired financing, public policy statements, a control base that has legal consequences, a basis for evaluating government performance, and the results of budget realization are outlined in government financial reports as a statement of the government's responsibility to the public. However, the budget and budget realization carried out by the government has limitations in measuring performance. This condition can occur because one of the measures of government performance is through an assessment of the effectiveness of budget realization, not only through financial figures, but also through the outcomes, benefits, and impact of budget realization for the community.

Hansen and Mowen (2009) describe that budget has four important benefits, namely (1) forcing executives to plan, (2) providing information that can be used to improve decision making, (3) providing performance evaluation standards, and (4) improving communication and coordination. Budget planning consists of budget policy formulation, namely the preparation of local government budget (Anggaran Pendapatan dan Belanja Daerah, APBD) direction and general policies as the basis for operational planning, and budget operational planning, such as the preparation of activity plans and resource allocation (Mahsun, 2013). Furthermore, Mahsun (2013) explains that at the budget execution stage there is a possibility of budget changes in the budget period and these changes are made in connection with strategic regional government policies, adjustments as a result of not achieving the set regional revenue targets, and urgent needs. These budget changes will then be discussed together with the regional House of Representatives (Dewan Perwakilan Rakyat Daerah, DPRD) and subsequently outlined in the direction and general policy of the APBD along with the changes in the strategy and priorities of the APBD. These two changes are stipulated by the regional head as a guideline for regional apparatus in preparing programs and budget changes.

Herianti (2019) specifies that the main issue of the budget planning process and budget execution is a budget deviation which is defined as a condition that indicates the failure of the government to control the budget which can cause a deficit or surplus. Several important issues of a budget deficit that have taken place in regency/city governments in Indonesia during the last two years, for example, the budget deficit of Rp9oo billion in the Bekasi city government in 2018. This budget deficit eventuated because of high government expenditure without taking regional revenue into account. Besides, in 2019 there was a budget deficit in the city government of Bandung which almost reached Rp609 billion. Such budget deficit occurred as local revenues had not reached optimal levels and unspent funds at end of the fiscal year (Sisa Lebih Penggunaan Anggaran, SILPA) was not as predicted. This condition has resulted in the city government of Bandung making direct expenditure efficient and encouraging increased regional revenue and retribution. The same condition also occurred in the West Bandung regency government which experienced a deficit of Rp73 
billion. This budget deficit eventuated because the revenue from land and building taxes was not achieved due to the new adjustment policy on the taxable value of the property (Nilai Jual Objek Pajak, NJOP) set by the government which affected the psychology of taxpayers. After all, taxpayers are not ready for the tax increases.

Johansson and Siverbo (2014) explain that in several countries in the world when there is a budget deficit, sanctions will be imposed. The budget deficit phenomenon that happens in regency/city governments does not only show that the government has failed to plan, implement, and control the budget. However, the budget surplus phenomenon also shows the same condition. When there is a budget surplus it shows that (1) the government is not obedient in implementing the previously planned budget. This condition is because the budget is determined politically between the government and the House of Representatives (Dewan Perwakilan Rakyat/Dewan Perwakilan Rakyat Daerah, DPR/DPRD), (2) the inability of the government to plan, implement and control the budget, and (3) the failure of the government to improve public welfare which can become the spotlight of the mass media. This condition is due to the characteristics of public service-oriented public sector organizations that allow budgets to be managed efficiently, effectively, and economically, to achieve budget balance. The balance of the budget while still taking into account the accuracy of budget realization and good budget absorption allows an increase in public welfare.

The phenomena of budget deficits and surpluses that took place in several regency/city governments throughout Indonesia indicate that the government has experienced a budget deviation. One of the important factors that play a role in influencing the occurrence of budget deviation is the budget forecast errors. Budget forecast errors indicate the government's tendency to increase estimated revenue and reduce expenditure estimates (Patty, 2019), or the condition of budget forecast that is too high or otherwise too low (Rodgers \& Joyce, 1996). Budget forecast analysis has an important role in economic policy (Boukari \& Veiga, 2018; Auerbach, 1999). This condition can occur because the budget forecast is a budget plan based on the various potential sources belonged to an organization. Revenue estimates that are too high can lead to shortcuts in the provision of public goods that have the potential to reduce public welfare. This means that when the government forecast a budget that is too optimistic, it has the potential to reduce public welfare in conditions of not achieving budget execution. This condition shows that the government has experienced an error in forecasting the budget. Jonung, Larch, Favero, and Martin (2006) revealed that budget forecast errors had contributed to an increase in structural deficits in European countries.

The forecast revenue budget that is too high and/or the expenditure budget that is too low at the regional level can increase the amount of debt, thereby reducing public welfare due to the interest burden borne by the government. Dubois (2016) explains that in the budget cycle theory, the budget is used as a means of government politics to the public. This condition occurs because the government tries to increase public trust through budget accountability. Accountability of government budgets to the public tends to not achieve budget balance but rather budget deficits or surpluses as a representation of budget deviations that have the potential to reduce public welfare. Budget deficits and surpluses indicate the existence of information asymmetry between the government and the public. This means that the government has excessive information compared to the public so that the government can take 
advantage of this excessive information to fulfill its interests. The government has more access to information related to the resources it has for the planning, implementation, and even budget control processes, while the public has limited access to potential resources.

Ariffianto and Adhariani (2018) explain that budgeting behavior is based on personal interests to avoid the risk of uncertainty or inability to predict future budgets. These personal interests are not only owned by the government, but also by regional representatives. The consequence is the potential for the estimated revenue budget that is too high and/or the expenditure budget that is too low at the regional level, thus affecting the occurrence of budget deviations. Patty (2019) describes that when the government incorrectly forecasts the budget, the budget deviation will be high. The optimism of the government in forecasting the revenue budget that is too high and/or the forecasting of the expenditure budget that is too low triggers budget variance. This condition results in the government being inaccurate in implementing public policies, thereby reducing the level of public welfare.

The appearance of budget forecast errors on budget deviation is reinforced by the existence of the government's overconfidence. Mofsinger (2010) explains that overconfidence is an excessive trust that makes individuals overestimate their knowledge and underestimate predictions made because individuals overestimate their abilities. The consequence is that the individual will bear a greater risk in the decision-making process. Overconfidence is a type of cognitive bias that leads to forecast errors because individuals feel they know, so they can analyze correctly, but in reality, it is not the case. The overconfidence literature on public sector organizations that focuses on financial data is still of limited use by various researchers.
This condition is caused by the difficulty of measuring overconfidence. Previous literature tends to focus on public companies to assess the overconfidence of managers and investors in decision-making. Therefore, this study is important to detect errors in the budget forecast in influencing budget deviations which are strengthened by the government's overconfidence.

The issue of overconfidence is still popular among financial behavior research (Huang, Jiang, Liu, \& Zhang, 2011; Koo \& Yang, 2018; Yang \& Kim, 2020). This condition is because overconfidence can influence the bias of individual decision making which has an impact on their level of prosperity. In public sector organizations, local governments have overconfidence because they feel they have excessive knowledge of access to resources they have in the planning, implementation, and even budget control processes that can influence decision making. This knowledge is used as the basis for the budget planning process through to budget execution. Local governments are said to experience overconfidence when there is a residue between budget growth and growth in budget realization. This means that the local government considers that budget planning based on its knowledge sources is capable of achieving budget realization, but this is not always the case. The estimated residual value between budget growth and budget realization growth that is more than zero indicates that local governments tend to be overconfident in budget planning.

Local government's overconfidence in budget preparation can strengthen the occurrence of budget forecast errors against budget deviations. This condition can occur because the overconfident government tends to perform an error in estimating the potential budget proposed. After all, it depends on its irrational beliefs. This means that the government is optimistic in planning the bud- 
get that budget realization will be achieved. When this cognitive bias is manifested in local governments, they show too much confidence in the presence of a budget deficit or surplus. Yang and Kim (2020) explain that if managers who have overconfidence invest excessively based on a biased optimistic view, their company's internal funds are likely to run out quickly. Individuals who have overconfidence tend to view that such risk is low compared to individuals who do not have overconfidence (Kartini \& Nugraha, 2015).

Based on the description of the research background above, the formulation of the research problem is whether the budget forecast errors affect budget deviation moderated by the local government's overconfidence? Thus, this study aims to examine and analyze the effect of budget forecast errors on budget deviation moderated by the local government's overconfidence.

\section{Budget Forecast Errors and Budget Deviation}

The principle of accountability has been widely applied in public sector organizations to achieve good governance. To minimize and narrow the opportunities for irregularities to occur and it is the obligation of the community to participate in conducting supervision (Dwiharja \& Kurrohman, 2013). One important aspect of accountability by public sector organizations is financial accountability. Surjono and Firdaus (2017) explain that financial accountability is related to financial integrity, disclosure, and compliance with laws and regulations. Financial integrity is related to the relationship or match between accounting numbers and descriptions also their sources. Disclosures are concerned with the design and presentation of financial reports as a collection of snapshots of economic events affecting public sector organizations for a period and contain sufficient information. Compliance with laws and regulations relates to financial reports prepared and published by public sector organizations per statutory provisions.

Organizations need a budget as a form of future financial planning that comprises of goals and actions needed by the organization in achieving organizational goals. In general, the organization's budget covers a period of one year and is expressed in monetary units (Mahsun, 2013). The important issue of budget deficits and surpluses shows that the government is experiencing a budget deviation. An important factor that motivates budget deviation is budget forecast error. Patty (2019) explains that budget forecast errors happen when the government makes high revenues and low expenditure estimates. The same condition was also explained by Rodgers and Joyce (1996) that the budget forecast errors occur because the government either overestimate or underestimate the expenditure of the budget. Overestimated revenue budgets and/or underestimated budgets at the regional level can increase the amount of debt. The consequence is that the government will pay an interest expense that can reduce public welfare. This means that the budget that should be used to meet the public interest is reduced because the government needs to pay interest expenses as a result of the government's failure in estimating the budget.

Organizations need a budget as a form of future financial planning that comprises of goals and actions needed by the organization in achieving organizational goals. In general, the organization's budget covers a period of one year and is expressed in monetary units (Mahsun, 2013). The important issue of budget deficits and surpluses shows that the government is experiencing a budget deviation. An important factor that motivates budget deviation is budget forecast error. Patty (2019) explains that budget forecast 
errors happen when the government makes high revenues and low expenditure estimates. The same condition was also explained by Rodgers and Joyce (1996) that the budget forecast errors occur because the government either overestimate or underestimate the expenditure of the budget. Overestimated revenue budgets and/or underestimated budgets at the regional level can increase the amount of debt. The consequence is that the government will pay an interest expense that can reduce public welfare. This means that the budget that should be used to meet the public interest is reduced because the government needs to pay interest expenses as a result of the government's failure in estimating the budget. Patty's (2019) findings show that budget forecast errors increase the occurrence of budget deviations. Based on this description, the researcher proposes the following hypothesis.

H1: Budget forecast error has a positive effect on the budget deviation.

\section{Budget Forecast Errors, Overconfi- dence, and Budget Deviation}

Previous literature examining overconfidence in the context of public sector organizations are limited. The importance of research related to overconfidence is motivated by individual psychological factors in making decisions that involve irrational behavior. The consequence is decision-making bias that has an impact on reducing individual welfare. In public sector organizations, local governments have overconfidence because they feel that they have excessive knowledge of access to resources they have in planning, implementation, and even budget control processes that can influence decision making. This knowledge is used as the basis for the budget planning process through to budget execution.

Budget forecast errors, overconfidence, and budget deviation represent the presence of information asymmetry. Jensen and Meckling (1976) explain that information asymmetry occurs because agents have more access to information than principals. In the context of public sector organizations, the agent is the local government and the principal is the community or the public. Local governments as agents have more access to information than the public, therefore local governments are aware of the various changes that have occurred in the budget and the instability of resources for budgeting (Patty, 2019). Ariffianto and Adhariani (2018) explain that budgeting behavior is based on personal interests to avoid the risk of uncertainty or inability to predict future budgets. These personal interests are not only owned by the government, but also by regional representatives. As a result, there will be potential revenue budget estimates that are too high and/or budget that is too low at the regional level, thus affecting the occurrence of budget deviations.

Auerbach (1999) states that the revenue forecast is an important input in designing fiscal policy, and the revenue forecast can reduce people's welfare. Repeated high estimates of revenue and/or underestimation of expenditure at the regional level indicate irrational behavior of the government in budget planning. This irrational behavior arises because the government considers that they have more ability to access information, thus ignoring the accuracy of local revenue sources. Ultimately, the increase in public welfare is reduced. Based on this description, the researcher proposes the following hypothesis.

$\mathrm{H} 2$ : Overconfidence has a positive effect on the relation of budget forecast errors with budget deviation.

Based on the description of the hypothesis above, the visualization of this research model is presented in Figure 1. 


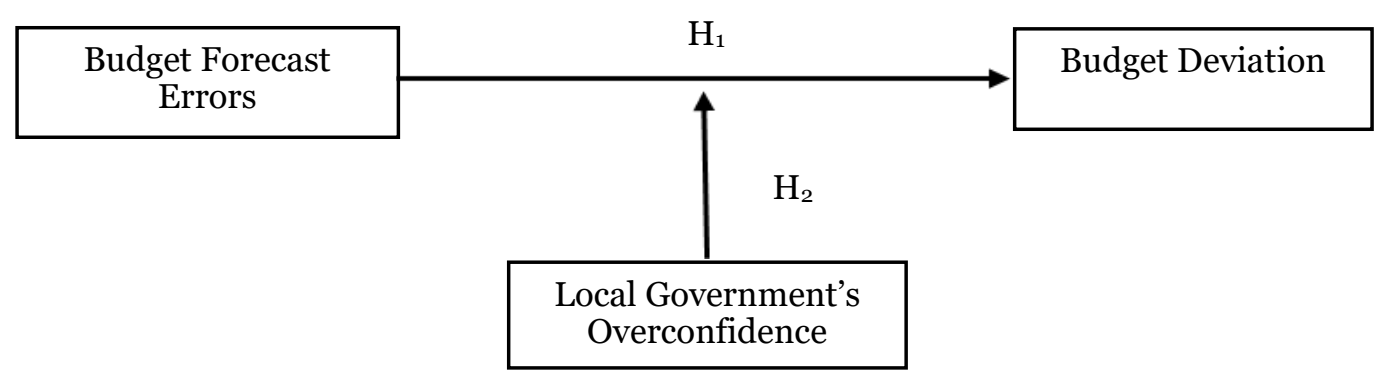

Figure 1. Research Model

\section{RESEARCH METHOD}

The author used local government regencies/ cities throughout Indonesia as research samples through the purposive sampling method. The data used in this study are budget reports and budget realization of all regency/ city governments in Indonesia which are obtained through the website www.djpk.go.id. The number of samples in this study was 1,524 namely 508 regency/city governments who uploaded budget reports and budget realization on the Directorate General of Fiscal Balance (Direktorat Jenderal Perimbangan Keuangan, DJPK) website during 2017-2019.
The variables of the budget forecast error, the overconfidence of regency/city government, and the budget deviation were used by researchers in this study. To be clearer regarding the use of these three variables, the operational definition, and measurement of the variables are presented in Table 1.

The ordinary least square (OLS) approach was used by researchers to test the research hypothesis. Therefore, researchers need to perform some classical assumption tests as a condition for using OLS. The aim is to minimize residuals to reduce bias in conclusions. In other words, the classical assumption test

Table 1. Operational Definition and Variables Measure

Definition
$\begin{aligned} & \text { Budget Forecast Errors (BFE) } \\ & \text { The estimated revenue budget that is } \\ & \text { too high and/or the estimated budget } \\ & \text { expenditure is too low (Patty, 2019) }\end{aligned}$
$\begin{aligned} & \text { Local Government Overconfidence } \\ & \text { (LGO) }\end{aligned}$

Source: Yang \& Kim (2020), Herianti (2019), Patty (2019), Boukari \& Veiga (2018); Wirasedana et al.(2018), Yang \& Zhang (2017), Johanson \& Siverbo (2014), Mofsinger (2010), Malmendier \& Tate (2005). 
aims to obtain BLUE (Best Linear Unbiased Estimator) research results. The classic assumption tests used by the researchers were the heteroscedasticity and autocorrelation tests, while the normality and multicollinearity tests were not used by the researchers. This condition is based on the number of observations of the sample of this study that have met or exceeded the requirements for the use of regression as described in the central limit theory, so the normality test is not mandatory for researchers (Gujarati \& Porter, 2009). Furthermore, the multicollinearity test is not used by researchers because it is not directly related to the residuals, therefore the data is still BLUE (Gujarati \& Porter, 2009; Widarjono, 2016). The author use White's Heteroscedasticity-consistent variance and standard error to correct the parameter values obtained by the ordinary least square method and the output can be directly used by researchers as the final result of hypothesis testing because the heteroscedasticity problem has been corrected (Ghozali \& Ratmono, 2017). Data does not have autocorrelation when the DW value range is 1.542.46 (Winarno, 2015).

\section{RESULT AND DISCUSSION}

Descriptive statistics aim to provide an overview or description of data seen from the mean and standard deviation. Table 2 presents the statistical descriptions of each variable. The number of observations obtained is 1,524 from the total sample of regency/city governments per year is 508 and calculated based on the three years of research, namely from 2017 to 2019. The mean value of the budget deviation variable is 0.987 which demonstrates that regency/city governments have failed in controlling their budget which can cause a surplus or deficit with a data variability of 4.516. The mean budget error value of 0.150 indicates that regency/city governments have budget forecast errors that are too high for revenue and/or budget estimates that are too low for expenditures with a data variability of 0.171 . The local overconfidence value of 0.415 indicates that regency/ city governments are overconfident in setting budgets and realizing the budget with a data variability of 0.492 .

Table 2. Descriptive Statistics

\begin{tabular}{cccc}
\hline Variables & $\mathbf{N}$ & Mean & Std. Deviation \\
\hline BDV & 1,524 & 0.987 & 4.516 \\
\hline BFE & 1,524 & 0.150 & 0.171 \\
\hline LGO & 1,524 & 0.415 & 0.492 \\
\hline
\end{tabular}

The correlation values between the research variables are shown in Table 3. Correlation shows a close relationship between the research variables. The higher the correlation value, the stronger the relationship between the research variables. The strong correlation value is between budget forecast errors and budget deviation. The strong correlation between the two variables shows that the higher the budget forecast errors, the higher the budget deviation that occurs in regency/ city governments. Furthermore, the second strong correlation value occurs between the overconfidence variable and the budget forecast errors. This condition shows that when local governments are overconfident in planning the budget, the budget forecast errors will be even higher.

Table 3. Correlation of each Variable

\begin{tabular}{cccc}
\hline Variables & BDV & BFE & LGO \\
\hline BDV & 1.000 & & \\
\hline BFE & 0.373 & 1.000 & \\
\hline LGO & 0.058 & 0.241 & 1.000 \\
\hline
\end{tabular}

The hypothesis test results are shown in Table 4. The first hypothesis, H1, explained that budget forecast errors had a positive effect on budget deviation. Meanwhile, H2 explained the effect of overconfidence on the relationship between budget forecast errors 
and budget deviations. The $\mathrm{H} 1$ test results indicate that the effect of budget forecast errors on budget deviation has a coefficient value of 9.865 and t-statistic of 3.278 at a significance level of $<1 \%$. The results of this test indicate that the budget forecast errors have a positive and significant effect on budget deviation, thus $\mathrm{H} 1$ is supported. These results are in line with Jonung et al., (2006) and Patty (2019), the budget forecast errors increase the occurrence of budget deviations.

The $\mathrm{H} 2$ test results show that the effect of overconfidence on the relationship between budget forecast errors and budget deviation has a coefficient value of 5.861 and t-statistic of 0.914 at a significance level of $>1 \%$ and $5 \%$ even $10 \%$. The results of this test indicate that overconfidence cannot moderate the effect of budget forecast errors on budget deviation so that $\mathrm{H}_{2}$ is not supported. Local governments that have overconfidence when preparing budgets are unable to strengthen the occurrence of budget forecast errors against budget deviations. This condition is due to the tendency of local governments to not use their irrational beliefs in formulating budgets due to the involvement of people's representatives in budget discussions. This means that the government is optimistic in planning the budget and therefore, the budget realization will be achieved based on objective financial data without involving dominant psychological factors. Therefore, the budget formulation that involves people's representatives allows the government to act rationally in formulating the budget, hence irrational beliefs that have an impact on overconfidence are reduced.

The author conducted additional tests to complement the results of this study to obtain comprehensive results in answering research issues. The additional test consists of two parts, namely, test the difference in overconfidence in regency/city government regarding budget forecast errors and budget deviation shown in Appendix 1 and test the research hypothesis based on categories of geographic areas in Indonesia, namely western, central, and eastern Indonesia shown in Appendix 2. Table 5 shows that the highest mean budget deviation occurs when regency/city governments have overconfidence compared to when they are not overconfident. This condition indicates that when the

Table 4. Hypothesis Results

\begin{tabular}{|c|c|c|c|}
\hline \multirow[t]{2}{*}{$\begin{array}{c}\text { Independent } \\
\text { Variables }\end{array}$} & $\begin{array}{c}\text { H1 } \\
\text { Least Square Method } \\
\text { Dependent Variable: BDV }\end{array}$ & \multicolumn{2}{|c|}{$\begin{array}{c}\text { H2 } \\
\text { Least Square Method } \\
\text { Dependent Variable: BDV }\end{array}$} \\
\hline & Coef. & Coef. & t-stat. \\
\hline BFE & $3,278 * * *$ & 7,368 & $10,114 * * *$ \\
\hline \multicolumn{2}{|l|}{ LGO } & $-2,245$ & $-1,214$ \\
\hline \multicolumn{2}{|l|}{ BFE* LGO } & 5,861 & 0,914 \\
\hline Const. & $-1,416$ & $-0,087$ & $-1,216$ \\
\hline $\mathrm{R}^{2}$ & 0.139 & \multicolumn{2}{|c|}{0.152} \\
\hline Adjusted $\mathrm{R}^{2}$ & 0.138 & \multicolumn{2}{|c|}{0.150} \\
\hline F-Stat. & $246.864 * * *$ & \multicolumn{2}{|c|}{$90.908 * * *$} \\
\hline Durbin-Watson Stat. & 2.000 & \multicolumn{2}{|c|}{2.000} \\
\hline $\mathrm{N}$ & 1,524 & \multicolumn{2}{|c|}{1,524} \\
\hline \multicolumn{4}{|c|}{$\begin{array}{l}\text { Note: BDV (Budget Deviation), BFE (Budget Forecast Errors), LGO (Local Government Overconfidence), BFE*LGO } \\
\text { (Interaction between Budget Forecast Errors, and Local Government Overconfidence). Free of autocorrelation based } \\
\text { Winarno (2015) with the rule of thumb } 1,54 \text { to } 2,46 . \text { Heteroskedasticity with white-hinkley (HC1) heteroskedasticity con- } \\
\text { sistent standard errors and covariance. Sig. } *, * * * * \text { level } 10 \%, 5 \%, 1 \% \text {. }\end{array}$} \\
\hline
\end{tabular}


regency/city governments are overconfident in setting and realizing the budget, the tendency for budget deviation is higher than when local governments have overconfidence. The same condition also applies to budget forecast errors. When regency/city governments have overconfidence in setting and realizing the budget, there is a tendency for budget forecast errors to become higher than when local governments are not overconfident.

Table 6 shows that the results of the multi-

Table 5. Descriptive Statistics

\begin{tabular}{|c|c|c|c|}
\hline Category & Mean & Std. Deviation & $\mathrm{N}$ \\
\hline \multicolumn{4}{|c|}{ Budget Deviation (BDV) } \\
\hline Overconfidence & 1.303 & 6.737 & 633 \\
\hline No overconfidence & 0.763 & 1.597 & 891 \\
\hline \multicolumn{4}{|c|}{ Budget Forecast Error (BFE) } \\
\hline Overconfidence & 0.199 & 0.175 & 633 \\
\hline No overconfidence & 0.115 & 0.159 & 891 \\
\hline
\end{tabular}

variate test aim to find out the differences between categories of regency/city governments that are overconfident or not overconfident related to budget forecast errors and budget deviations. The findings of this study indicate that there are differences between categories of regency/city governments that are overconfident or not overconfident related to budget forecast errors and budget deviations. This condition is shown by the significant Lawley-Hotelling trace value at the level $<1 \%$. The author uses this value because there are two groups of dependent variables, namely budget forecast errors and budget deviation.

Table 6. Additional Results of Multivariate

\begin{tabular}{lcc}
\hline \multicolumn{1}{c}{ Source } & Statistic & F Statistic \\
\hline Wilks' Lambda & 0.941 & $48.086^{* * *} \mathrm{e}$ \\
\hline Pillai's Trace & 0.059 & $48.086^{* * *} \mathrm{e}$ \\
\hline Lawley-Hotelling Trace & 0.063 & $48.086^{* * *} \mathrm{e}$ \\
\hline Roy's Largest Root & 0.063 & $48.086^{* * *} \mathrm{e}$ \\
\hline
\end{tabular}

Table 7. Additional Results of Test Between Subjects Effect

\begin{tabular}{lcccc}
\hline Source & SS & Df & MS & F \\
\hline \multicolumn{5}{l}{ Based on } \\
\hline BDV & 107.978 & 1 & 107.978 & $5,309^{* *}$ \\
\hline BFE & 2.599 & 1 & 2.599 & $94,284^{* * *}$ \\
\hline Based on Geographic Area Category & & \\
\hline BDV & 17.479 & 2 & 8.740 & 0.428 \\
\hline BFE & 0.029 & 2 & 0.015 & 0.504 \\
\hline
\end{tabular}

Table 7 shows the test of between-subject effects to test the different categories of regency/city governments are overconfident or are not overconfident related to budget forecast errors and budget deviation. The research findings show that there are different categories of regency/city governments that are overconfident or not overconfident related to budget forecast errors as indicated by the F-statistic value of 94.284 at the level < $1 \%$ and budget deviation indicated by the Fstatistic value of 5.309 at the level $<1 \%$. If linked with Table 5 , it can be seen that the highest mean value of budget deviation and budget estimate occurs when regency/city governments are overconfident compared to those that are not overconfident. This condition shows that when regency/city governments are overconfident in setting and realizing the budget, there is a tendency for more budget forecast errors and budget deviation to become higher compared to local governments that are not overconfident. Table 7 also shows the test of between-subject effects to examine differences in the categories of regency/city governments in western, eastern, and central Indonesia related to budget forecast errors and budget deviations. The findings of the study show that there are no differences in the categories of regency/city governments in the three regions related to budget forecast errors as indicated by the F-statistic value of 0.504 and 
budget deviation indicated by the F-statistic value of 0.428 .

The purpose of the multivariate test on the geographic area category was to find out the differences between the categories of regency/city governments in western, eastern, and central Indonesia regarding budget forecast errors and budget deviations. The findings of this study indicate that there is no difference between the categories of regency/city government in the three regions regarding budget forecast errors and budget deviations. This condition is indicated by the insignificant Lawley-Hotelling trace value at $1 \%, 5 \%$, and $10 \%$ levels.

The additional results of geographic area category test results for western, central, and eastern Indonesia regions shown in Appendix 1 are consistent with the main test results. This condition can be seen through the results of the model I test for the three significant area categories at the level of $<1 \%$. This means that the budget forecast error has a positive and significant effect on the budget deviation in the three regions. The Central Indonesia region has the most significant influence as indicated by the adjusted $\mathrm{R} 2$, which is $88.5 \%$ at the level of $<1 \%$ compared to the categories of eastern and western Indonesia. Furthermore, these findings also indicate that overconfidence cannot moderate the effect of budget forecast errors on the budget deviation. This condition indicates that regency/city governments are overconfident in setting and realizing budgets cannot affect the relationship between bud-get forecast errors and budget deviation.
Appendix 2 shows that the highest mean value of budget deviation occurs in the regency/city government category in the eastern Indonesia region, compared to the western and central regions of Indonesia. The same conditions apply to budget forecast errors. This condition shows that regency/city governments in eastern Indonesia have failed to control the budget which can cause a surplus or deficit which tends to be higher than regency/city governments in the western and central regions of Indonesia. Furthermore, regency/city governments in eastern Indonesia also have errors where budget estimates that are too high for revenue and/or budget estimates that are too low for expenditures tend to be higher than regency/city governments in western and central Indonesia.

Table 8 shows the results of the multiple comparison test through the Tukey test to detect the difference between the three categories of western, central, and eastern Indonesia related to budget forecast errors and budget deviations. These findings indicate that the three categories of western, central, and eastern Indonesia do not have significant differences concerning budget forecast errors and budget deviations. This condition is known through the average value of differences in budget forecast errors and budget deviations thawt are not too far apart between the three categories of regions, so they do not have a significant impact. This means that regency/city governments in the western, central, and eastern regions of Indonesia have no differences in controlling budgets which can cause a surplus or deficit and an error in the budget forecast that is too high

Tabel 8. Additional Results of Geographic Area Category (Multiple Comparison)

\begin{tabular}{lcc}
\hline \multicolumn{1}{c}{ Region } & Mean Difference \\
\cline { 2 - 3 } & BDV & \\
\hline Western Indonesia vs Central Indonesia & 0,090 & 0,005 \\
\hline Western Indonesia vs Eastern Indonesia & 0,270 & 0,013 \\
\hline Central Indonesia vs Eastern Indonesia & 0,361 & 0,007 \\
\hline
\end{tabular}


for revenue and/or an underestimation of the budget for expenditure.

\section{CONCLUSION}

The findings of this study indicate that budget forecast errors have a positive and significant effect on budget deviation, and overconfidence cannot moderate the effect of budget forecast errors on the budget deviation. The findings of this study also show that regency/city governments that are overconfident tend to fail in controlling their budget which can cause a surplus or deficit compared to local governments that are not overconfident. The same conditions apply to budget forecast errors. This means that regency/city governments that are overconfident tend to overestimate budgets for revenue and/or underestimate budget for expenditure compared to local governments that are not overconfident. Consistent with the main test results, this study shows that budget forecast errors had a significant effect on budget deviation and tend to occur in the Central Indonesian region category. Furthermore, the overconfidence of regency/city governments cannot moderate the effect of budget forecast errors on budget deviations. Finally, these findings indicate that there is no difference between the budget forecast errors and the budget deviation in the three categories of western, central, and eastern Indonesia.

The contribution of this research to theory is that local government budgets are used as a political tool to increase public accountability, therefore it is consistent with the budget cycle theory. Accountability of government budgets to the public aims to increase public confidence that the government has worked under applicable regulations. The budget is outlined in financial planning as an instrument of local government to describe the future of public policies that will benefit the public to gain political support. Also, budget planning to the budget execution stage tends to experience information asymmetry, therefore it is consistent with agency theory. This condition can occur because local governments have more access to the potential of human resources and use excess access to fulfill their interests, while the public is limited in accessing information. This condition can be identified by the existence of deficits and surpluses that occur in local governments. The result is that public welfare is reduced because the budget that should be used for the public interest is not properly absorbed.

The contribution of this study in methodology is the measurement of government overconfidence using secondary data in the context of public sector research allows researchers to modify the overconfidence measurement in the public sector context. The author adapted the research of Malmendier and Tate (2005), Yang and Zhang (2017), also Yang and Kim (2020) to measure overconfidence based on the regression results of asset growth on sales growth. The logic of this measurement is when the residual value of the regression results greater than zero indicates that the company manager has overconfidence. This condition is because company managers have confidence that asset growth will be able to increase sales growth. However, if there is a residual or difference between the actual data and the regression results, it shows that the manager has overconfidence because the asset growth rate is not able to achieve the sales growth rate. Using the same logic, the researcher modified the overconfidence measurement in the context of the public sector by regressing the growth of the revenue budget against the growth in revenue realization. That is, when the residual value of the regression results is greater than zero, it indicates that the local government has been overconfident. This condition is because local governments have confidence that budget growth will be able to 
increase growth in realization. However, if there is a residual or difference between the actual data and the regression result data, it shows that the local government has overconfidence because the growth rate of the revenue budget is not able to achieve the growth rate of revenue realization.

The policy contribution of this research is (1) the priority of regency/city government programs must be able to respond to changes that occur in the future and be able to balance public interests and be accountable for the lives of its citizen. As a result of this lack of attention, it has a negative impact on budget forecast errors which can affect the occurrence of budget deviations. This phenomenon can be seen through the existence of budget deficit cases in several regency/city governments in Indonesia, and (2) regency/ city governments need to pay attention to underspending and overspending which shows the financial achievements of each sector or organizational unit in the local government. The process of assessing the difference between underspending and overspending requires clear Expenditure Analysis Standards (Standar Analisis Biaya, SAB), Performance Benchmarks and Cost Standards, and Minimum Service Standards (Standar Pelayanan Minimal, SPM) (Mahsun, 2013).

The author realizes that every study has its limitations. Therefore, the limitations of this study are (1) measuring overconfidence which is still difficult in public sector financial accounting literature, hence researchers only use measurements that refer to research modified by researchers according to the context of this study, and (2) the adjusted R2 value of Main hypothesis testing ranging from $11 \%-15 \%$ indicates that the variables used by researchers are only able to explain the phenomenon by $11 \%-15 \%$. Therefore, the description of these two limitations provides an opportunity for further research to further explore the measurement of overconfidence in public sector financial accounting, and use other variables that can affect budget deviation in answering research issues such as budget turbulence, measurement, performance based on value for money, local government skills, and other variables.

\section{REFERENCES}

Ariffianto, M., \& Adhariani, D. (2018). Budget surplus determinants in Indonesian regional government budgets from a budgetary slack behavior point of view. International Journal of Economics and Management, 12 (Specialissue1), 17-29.

Auerbach, A. J. (1999). On the performance and use of government revenue forecast. National Tax Journal, 52(4), 767782.

Boukari, M., \& Veiga, F. J. (2018). Disentangling political and institutional determinants of budget forecast errors: A comparative approach. Journal of Comparative Economics, 46(4), 10301045. DOI: 10.1016/j.jce.2018.03.002

Dubois, E. (2016). Political business cycle 40 years after Nordhaus. Public Choice, 166(1), 235-259.

Dwiharja, L. M., \& Kurrohman, T. (2013). Pengaruh akuntabilitas dan transparansi pengelolaan Anggaran Pendapatan dan Belanja Sekolah (APBS) terhadap partisipasi Komite Sekolah. Jurnal Riset Akuntansi dan Keuangan, 1(3), 182-194. DOI: 10.17509/ jrak.v1i3.6696

Ghozali, I., \& Ratmono, D. (2017). Analisis multivariate dan ekonometrika: Teori, konsep, dan aplikasi dengan Eviews 10. Semarang: Badan Penerbit Universitas Diponegoro.

Gujarati, D., \& Porter, D. C. (2009). Basic econometrics (5th Ed.). New York: McGraw-Hill.

Hansen, D. R., \& Mowen, M. M. (2009). Akuntansi manajerial (Edisi 8). Jakarta: Salemba Empat.

Herianti, E. (2019). Budget turbulence and budget deviation: Do local governments have the ability to reduce 
them?. Jurnal Tata Kelola dan Akuntabilitas Keuangan Negara, 5(1), 120. DOI: 10.28986/jtaken.v5i1.285

Huang, W., Jiang, F., Liu, Z., \& Zhang, M. (2011). Agency cost, top executives' overconfidence, and investment-cash flow sensitivity: Evidence from listed China. Pacific-Basin Finance Journal, 19(3), 261-277.

Jensen, M. C., \& Meckling, W. H. (1976). Theory of the firm: Managerial behavior, agency cost, and ownership structure. In: Brunner K. (eds) Economics Social Institutions. Rochester Studies in Economics and Policy Issues, $1,163-231$. DOI: 10.1007/97894-009-9257-3_8

Johansson, T., \& Siverbo, S. (2014). The appropriateness of tight budget control in public sector organizations facing budget turbulence. Management Accounting Research, 26, 271-283. DOI: 10.1016/j.mar.2014.04.001

Jonung, L., Larch, M., Favero, C. A., \& Martin, P. (2006). Improving fiscal policy in the EU: The case for independent forecast. Economics Policy, 21(47), 491-534.

Kartini, K. \& Nugraha, N. F. (2015). Pengaruh illusions of control, overconfidence dan emotion terhadap pengambilan keputusan investasi pada investor di Yogyakarta. Jurnal Inovasi dan Kewirausahaan, 4(2), 115-123. DOI: 10.20885/ ajie.vol4.iss2.art6

Koo, J., \& Yang, D. (2018). Managerial overconfidence, self-attribution bias, and downwardly sticky investment: Evidence from Korea. Emerging Market Finance Trade, 54, 144-161. DOI: 10.1080/1540496X.2017.1398643

Mahsun, M. (2013). Pengukuran Kinerja Sektor Publik. Edisi Pertama. Yogyakarta: BPFE.

Malmendier, U., \& Tate, G. (2005). CEO overconfidence and corporate investment. The Journal of Finance, 60(6), 2661-2700. DOI: 10.1111/j.15406261.2005.00813.x

Mofsinger, J. R. (2010). The psychology of investing (4th Ed.). New Jersey: Precentice-Hall Inc.

Patty, J. R. (2019). Budget forecast errors and budget deviation: Financial capability index as a moderating variable. Jurnal Tata Kelola dan Akuntabilitas Keuangan Negara, 5(2), 157-175. DOI: $10.28986 /$ jtaken.v5i2.353

Ratmono, D., \& Sholihin, M. (2017). Akuntansi keuangan daerah berbasis akrual. Yogyakarta: UPP STIM YKPN.

Rodgers, R., \& Joyce, P. (1996). The effect of underforcasting on the accuracy of revenue forecast by state governments. Public Administration Review, 56(1), 48-56. DOI: 10.2307/3110053

Surjono, W., \& Firdaus, N. R. (2017). Pengaruh sistem akuntansi keuangan daerah terhadap akuntabilitas laporan keuangan pada satuan kerja Dinas Pendapatan dan Pengelolaan Keuangan (DPPK) pemerintah daerah Kabupaten Bandung. Jurnal Riset Akuntansi \& Keuangan, 5(1), 13571368. DOI: 10.17509/jrak.v5i1.6737

Widarjono, A. (2016). Ekonometrika: Pengantar dan aplikasinya disertai panduan Eviews. Yogyakarta: UPP STIM.

Winarno, W. W. (2015). Analisis ekonometrika dan statistika dengan Eviews. Yogyakarta: UPP STIM.

Wirasedana, I. W. P., Sisdayani, E. A., \& Setiawan, I. P. E. (2018). Kendali budget ketat pada pemda di Provinsi Bali dalam menghadapi turbulensi budget. E-Jurnal Akuntansi Universitas Udayana, 25(1), 300-327. DOI: 10.24843/EJA.2018.v25.io1.p12

Yang, D., \& Kim, H. (2020). Managerial overconfidence and manipulation of operating cash flow: Evidence from Korea. Finance Research Letters, 32 (C), 1-8. DOI: 10.1016/ j.frl.2019.101343

Yang, D., \& Zhang, Z. (2017). Impact of managerial optimism on cost stickiness: Evidence from China. International Journal of Applied Business and Economic Research, 15(21), 373-383. 


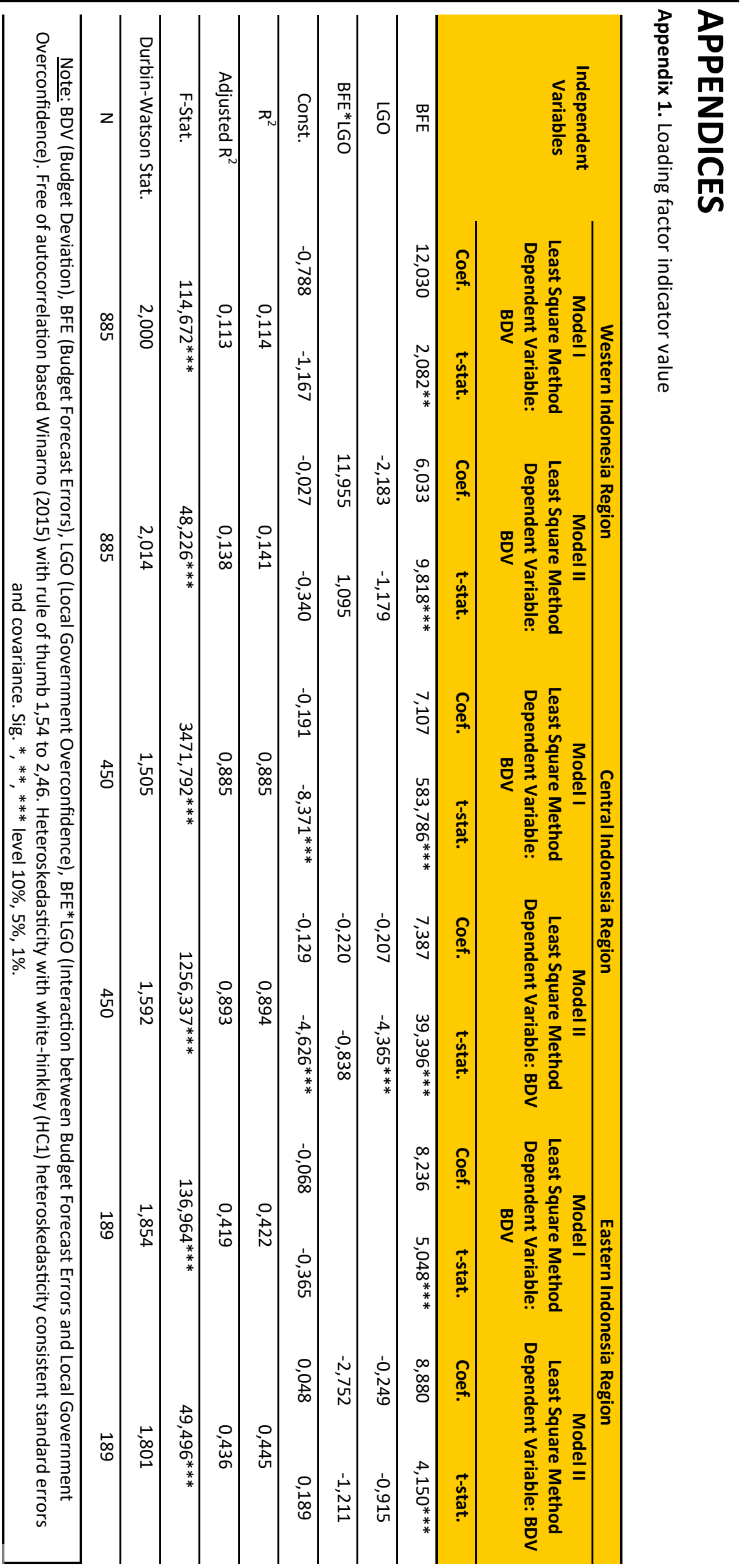


JURNAL TATA KELOLA DAN AKUNTABILITAS KEUANGAN NEGARA, Vol. 6, No. 2, 2020: 179-194

Appendix 2. Additional Results of Geographic Area Category (Descriptive Statistics)

\begin{tabular}{llll}
\hline \multicolumn{1}{c}{ Category } & Mean & Std.Dev & $\mathbf{N}$ \\
\hline BDV & & & 885 \\
\hline Western Indonesia Region & 0,981 & 5,719 & 450 \\
\hline Central Indonesia Region & 0,890 & 1,279 & 189 \\
\hline Eastern Indonesia Region & 1,251 & 2,723 & 885 \\
\hline BFE & & 0,161 & 450 \\
\hline Western Indonesia Region & 0,147 & 0,169 & 189 \\
\hline Central Indonesia Region & 0,152 & 0,215 & \\
\hline Eastern Indonesia Region & 0,160 & & \\
\hline
\end{tabular}

